\title{
A FÉLÉVES EGYÉNI ÖSSZEFÜGGÖ GYAKORLAT EREDMÉNYESSÉGE AZ INTÉZMÉNYVEZETŐK, HALLGATÓK ÉS MENTOROK VÉLEMÉNYE ALAPJÁN
}

\section{KOTSCHY BEÁTA ${ }^{*}-$ MOGYORÓSI ZSOLT ${ }^{* *}-$ TASKÓ TÜNDE $^{* * *}$}

\author{
* a Sapientia Szerzetesi Hittudományi Főiskola \\ professor emeritusa \\ beata@kotschy.hu \\ ** az Eszterházy Károly Főiskola Neveléstudományi Tanszék \\ mogyorosizs@ektf.hu \\ *** az Eszterházy Károly Főiskola Pszichológia Tanszék \\ taskot@ektf.hu
}

Az alábbi tanulmány ${ }^{1}$ a Bologna-rendszerü tanárképzés bevezetésével meginduló féléves összefüggö egyéni iskolai gyakorlat tapasztalatait gyüjti össze, s az eredmények alapján javaslatokat fogalmaz meg az egyéves összefüggö gyakorlat tartalmára, szervezésére vonatkozóan.

\section{A téma indoklása}

A Bologna-rendszerü pedagógusképzés bevezetéséhez kapcsolódó összefüggő féléves pedagógiai gyakorlat, általánosan elfogadott és deklarált szükségletet igyekezett kielégíteni, a leendő tanárok gyakorlati szakmai tudásának színvonalemelését, pedagógiai képességeik fejlesztését. Az új rendszer kiépítése alapvetően az egyetemi képzésben alkalmazott szakonként féléves komplex gyakorlat tapasztalataira épült, amely a szakos órák megtartásán túl különböző feladatokat fogalmazott meg a tanórán kívüli tevékenységek, s az intézmény életében való aktív részvétel terén. Ezeknek a komplex elvárásoknak a teljesítése a képzési rendszer liberalizálódásával, a kreditrendszer bevezetésével egyre nehezebbé és irreálisabbá vált. Ez indokolta egy szigorúbban szervezett új gyakorlati rendszer kidolgozását és bevezetését, amely ketté választotta a tanítási, ún. csoportos és a féléves egyéni összefüggő pedagógiai gyakorlatot. Míg az első kiemelt feladata a szaktanári képességek fejlesztése maradt, a második kibővítette a hallgató számára előírt pedagógiai tevékenységeket, a különböző pedagógusszerepek gyakorlásának körét. Szakmai szempontból fontos új vonása lett ennek a rendszernek, hogy míg a tanítási gyakorlat

\footnotetext{
${ }^{1}$ A tanulmány a TÁMOP-4.1.2.B.2.-13/1-2013-0005 pályázat.K/3-1. almodul keretében készült.
} EKF 2014. 
színhelyének általában a gyakorlóiskola lett kijelölve, az összefüggő gyakorlatot már egy „általános” színvonalú és összetételü intézményben kellett megszervezni, $\mathrm{s}$ csak az elméleti tanulmányok lezárása után lehetett megkezdeni.

A bevezetést megelözö szakmai viták három kérdés köré csoportosultak:

- Milyen feladatokkal kell megbízni a pedagógusjelöltet? A szakmai fejlödés/fejlesztés különböző területei milyen arányban kapjanak lehetőséget a félév során?

- Hogyan történjék a hallgatók segítése ebben a fejlődési folyamatban? Szükség van-e mentorálásra, $\mathrm{s}$ ha igen a mentor azonos szakos végzettséggel rendelkezzék-e? Hogyan motiválhatók a tapasztalt tanárok mentori munkára? Feltételként elöírható-e a szükséges szakmai továbbképzés elvégzése?

- Hogyan szervezhető meg a gyakorlat? Hogyan választható ki a gyakorlóhelyek hálózata? Hogyan oldható meg a felsőoktatási és a közoktatási félév struktúrája közti eltérés?

Az első kérdéskörben két eltérő megközelítés ütközött a szaktárgyi tanítás súlyának megítélésében. Míg a kollégák egy része úgy vélte, a csoportos egyéni gyakorlat már biztosította az oktatáshoz szükséges képességek fejlődését, s így a féléves gyakorlatban a hangsúlyt az intézményi müködés és a tanítási órákon túl megjelenő feladatokra kell helyezni, a másik tábor úgy vélte, hogy amíg a jelölt bizonytalan szaktanári müködésében, nem fog tudni többi feladatára sem eredményesen felkészülni.

A mentorok kiválasztási szempontjára adott eltérő feleletek az első kérdésre adott válaszból logikusan következtek. Azok, akik a szakórák megtartásában már nagyobb önállóságot kívántak adni a jelölteknek, kevésbé tartották fontosnak a mentor és hallgatója szakos megegyezését. Végül a harmadik kérdést a „bürokratikus” elöírások döntötték el, az egyetemi-föiskolai munkarend merev betartását követelve meg.

\section{A vizsgálat célja}

A Bologna-rendszerủ tanárképzés bevezetése óta 4-5. évfolyam pedagógusjelöltjei végezték el az összefüggő, egyéni féléves gyakorlatot. Ez az időtartam elégséges ahhoz, hogy megfelelö mennyiségü tapasztalat gyüljön össze, kirajzolódjanak a rendszer pozitív és negatív sajátosságai. Jelen időszakban, amikor az osztatlan tanárképzés bevezetésével ez az egyéni gyakorlat fél évről egy évre bővül, s az oktatási szakemberek feladata ismét választ adni ennek a gyakorlati évnek tartalmi, szervezési, finanszírozási kérdéseire, megnő az eddigi tapasztalatok feltárásának, elemzésének, értékelésének fontossága és szükségessége, hiszen a levont következtetések képezhetik az alapját az egyéves rendszer meghatározásának. Ennek a fejlesztési folyamatnak megalapozását kívántuk vizsgálatunkkal segíteni. 


\section{A feltárásban résztvevők és a feltárás módszerei}

Az előzetes tervek alapján három csoport tapasztalatainak összegyüjtésére vállalkoztunk a gyakorlatot elvégzett hallgatók, az őket támogató mentorok és a gyakorlóhelyet biztosító intézmények vezetőinek írásbeli kikérdezésével. A tervezett létszám 500 fö volt, elsősorban az észak-magyarországi régió gyakorlóhelyeinek igazgatói, mentorai és az EKF gyakorló hallgatói közül kerültek ki. Mivel a több mint 500 kiküldött kérdőívnek mindössze 10 százalékát kaptuk vissza, a mintavételt kiterjesztettük az ELTE és a Nyugat-Magyarországi Egyetem hallgatóira, gyakorlóhelyeinek intézményvezetöire és mentoraira. A végső eredmény 150 feldolgozható kérdőív lett. Ezen belül a hallgatók és mentorok aránya kb. 40 és 50 százalék, míg az intézményvezetők a válaszok kb. 10 százalékát adták.

Az intézmények különböző szempontok (típus, nagyság, székhely) szerinti differenciált vizsgálata a kis létszám miatt szakszerütlen következtetésekre adott volna okot, ezért mellőztük. A kérdőívek esetleges visszaküldése alapján azt sem lehetett biztosítani, hogy az egyes hallgatókat saját mentoraikkal együtt vizsgáljuk, így a közöttük kialakuló kölcsönhatásokat, illetve az intézményi sajátosságok befolyását sem tudtuk feltárni. A három csoport közötti összefüggések vizsgálata így nem vált lehetővé. Mindössze arra vállalkozhattunk, hogy - nem törekedve a reprezentativitásra - a vezetőket, mentorokat és gyakorló hallgatókat egységes csoportként kezeljük, s olyan kérdőívet dolgozzunk ki, ahol a három csoport alapkérdései megegyeznek. Elsősorban tehát nem az összehasonlítás indokolta ezt, hanem a fontos problémák többszempontú megközelítése. Mindhárom kérdőív tartalmaz a résztvevői csoportra jellemző sajátos kérdéseket is, s végül minden résztvevőtől kértük, hogy meglévő tapasztalatai alapján fogalmazzon meg javaslatokat az egyéves gyakorlat kialakítására vonatkozóan.

Jelen tanulmányunkban a vizsgálatból kiemeltük azt a három kérdéskört (szervezési tartalmi és módszertani, főként a mentorálásra vonatkozó kérdéseket), amelyek kezdettől fogva vitatottak voltak. ${ }^{2}$

\section{Az eredmények bemutatása}

A három csoport kérdőívei külön-külön és együttesen is feldolgozásra kerültek. Az egyes részek eredményei a tanulmány önálló alfejezetét képezik, majd a három kérdöív összehasonlító vizsgálata, a közösen megfogalmazott eredmények és következtetések, javaslatok alkotnak új alfejezetet.

\footnotetext{
${ }^{2}$ A minta differenciált bemutatását és a teljes kérdőív anyagának eredményeit egy következő tanulmányban foglalják össze a szerzők.
} 
Az összefüggö gyakorlat szervezési kérdései.

A gyakorlat szervezése az intézményvezetök nézőpontjából

A kérdések első csoportja a gyakorlóintézmény kiválasztásának és a gyakorlat megszervezésének körülményeire vonatkozott. Előzetes feltételezésünk szerint az intézményválasztásnál több szempont is nehezíthette a szervezést, az iskolák elzárkózása a plusz feladat elöl, a mentori segítségnyújtás megoldatlansága, illetve a képzö- és a gyakorlóhely közötti távolság.

A kisszámú vezetői válasz (22) nem igazolta a nehézségeket, mivel a 22 válaszból 20 hivatkozott előzetes tapasztalatokra, ismeretségre (8) és személyes információkra (12). Mindössze két esetre utaltak, ahol a képzőintézmény beosztása alapján kapott helyet a hallgató az iskolában. Valószínúleg a hallgatók egy része saját munkahelyén vagy régi iskolájában végezte gyakorlatát. Erre a hallgatói kérdőivek adtak pontosabb választ. Ugyanakkor megállapítható, hogy magának a képzőintézménynek kevés esetben kellett gyakornokát „elhelyezni”. Ez megkönynyítette a szervezés feladatait, de feltehető, hogy ez a szakmai igények korlátozását is jelenthette.

A gyakorlóhelyek megnevezése arról tanúskodik, hogy a hallgatók 22 százaléka olyan intézményben volt, ahol csak gimnáziumi programok voltak, vagyis ök feltehetően a gyakorlóiskolákra jellemző homogénebb szociokulturális háttérrel találkozhattak. A hallgatók három százaléka szakiskolában, és további 10 százalékuk községi iskolában, azaz ugyancsak homogénebb, ámde hátrányos helyzetű tanulókat nevelő intézményekben gyakoroltak.

A hallgatók 65 százaléka feltételezhetően vegyes, vagyis heterogénebb társadalmi összetétellel jellemezhető iskolákban töltötte el féléves gyakorlatát. Ez öszszességében teljesíti a hallgatók 78 százalékánál (ha idevesszük a jelentős számban hátrányos helyzetü tanulókat nevelő intézményeket is) azokat az elvárásokat, hogy találkozzanak a gyakorlóiskolától eltérő társadalmi összetételü diákpopulációval.

A gyakorlat megszervezése általában azonos forgatókönyv szerint történt, az iskolai munkabeosztása logikája szerint. Az igazgatók közül mindössze hárman jelezték, hogy nehézségeik voltak:

- az időpontok egyeztetésében;

- a gyakorlók iskolai és képzőintézményi elfoglaltságának összehangolásában;

- $\mathrm{s}$ az iskolai feladatok sokszínüségében, ,a tanmenet feszített tempójában” mivel így nem tudtak kellő óramennyiséget biztosítani a tanítási kompetencia megfelelő fejlesztésére. 


\section{Az összefüggő gyakorlat tartalmi elemei}

Elvárások a pedagógiai tevékenységek mennyiségével kapcsolatban

A féléves gyakorlat elökészítése során a szakértők között a legnagyobb vitát a különbözö pedagógiai tevékenységek mennyiségére vonatkozó elvárások váltották ki. Ez a vita burkoltan a szaktanári feladatok és az általános nevelési, pedagógiai feladatok súlyának eltérő megítéléséből fakadt. Ez indokolta, hogy a kérdőívben információkat gyüjtsünk arról, hogy az intézményvezetők, mentorok és hallgatók hogyan vélekednek a rendeletileg elöírt feladatok fontosságáról, illetve a gyakorlatban hogyan tudták megvalósítani azokat.

Bevezető kérdésként egy háromjegyü skálán az általános véleményüket fejezhették ki a megkérdezettek. A válaszok teljes egyetértést mutattak a féléves gyakorlat szükségességével, bevezetésével és célkitüzéseivel. Ezt követte a konkrét feladatok kívánatos súlyozása saját véleményük szerint, illetve a megvalósítás alapján. Az egyes tevékenységekre fordított idők összesen 100 százalékot tehettek ki. A kitöltés során a három csoport (intézményvezetők, hallgatók és mentorok) nem egyformán értelmezte a feladatot, így a kapott eredmények vizsgálatánál csak az igazgatók és gyakorlók véleményének, az elöírt tevékenységek rangsorának összevetésére volt lehetőség. Az 1. táblázat ezt a két rangsort mutatja be.

1. táblázat: A központilag előírt és a gyakorlatban megvalósuló szerint hallgatói tevékenységek rangsora az igazgatók és a hallgatók véleménye szerint

\begin{tabular}{|l|c|c|}
\hline Központilag elöírt tevékenység & $\begin{array}{c}\text { Igazgatók } \\
\text { rangsora }\end{array}$ & $\begin{array}{c}\text { Hallgatók } \\
\text { rangsora }\end{array}$ \\
\hline 1. A szaktárgy tanítása & 1 & 1 \\
\hline 2. Felkészülés a tanításra & 2 & 2 \\
\hline 3. A tanítás értékelése & 3 & 3 \\
\hline 4. Tanári adminisztráció ismerete & 4 & 6 \\
\hline 5. Tanórán kívüli tehetséggondozás, szakkör stb. & 5 & 7 \\
\hline 6. Osztályfónöki tevékenység & 6 & 9 \\
\hline 7. Az iskola szervezetének, szabályozóinak megismerése & 7 & 8 \\
\hline 8. Felzárkóztatás, korrepetálás & 8 & 11 \\
\hline 9. Iskolai rendezvényekbe való bekapcsolódás & 9 & 5 \\
\hline 10. Pedagógiai munkát segítő szakmai hálózat megismerése & 10 & 4 \\
\hline 11. Tanulószobai, napközis, illetve délutáni foglalkozások & 11 & 10 \\
\hline
\end{tabular}


Az első három feladatot kiemelten magas százalékos aránnyal jelölték legfontosabbnak az igazgatók, hallgatók és mentorok egyaránt. A rendelkezésre álló idő kb. 60 százalékát tölti ki a tanórai tevékenység három fázisa. A 4-6. ranghely átlagosan már csak 7,- 6 százalékkal szerepelt, míg a 7-11. rangsorban kapott értékek 4 és 2 százalék körül voltak. A reális értékeléshez szükség lenne a gyakorlat összes óraszámának pontos meghatározására, de az adatok olyan nagy eltéréseket mutatnak, hogy csak becsülni lehet az egyes százalékos értékek mögött lévő konkrét óramennyiséget. (A teljes gyakorlat időtartama kb. átlagosan 90-100 óra a félév során, így a két százalék mindössze egy dupla órányi foglalkozást jelent.)

A két rangsor különbségei fontos információkkal szolgálnak. Vannak olyan eltérések (5., 6., 8., 11. tevékenység), amelyek a tanulókkal való egyéni és differenciált foglalkozásra, illetve az osztályfőnöki feladatokra vonatkoznak. Ezeket a hallgatók hátrább sorolják, kevésbé tartják a féléves gyakorlat feladatának. A 8. és 11. tevékenység esetében az eltérés abból is származhat, hogy a hallgatók nagyobb hányada középiskolákban gyakorolt. Lényeges szemléletbeli különbséget mutat a 9. és 10. tevékenység megítélése, amelyeket a vezetők a legkevésbé fontos kategóriába sorolták, míg a hallgatók az 5. és 4 . helyen említették.

A fontossági sorrendben mutatkozó különbségek mellett egyöntetủ vélemény volt minden tevékenységnél, hogy kevés a rájuk fordítható idő, a félév alatt csak felületes ,ismerkedésre” van lehetőség, ezért várják az egyéves gyakorlat bevezetését, amely majd a nem tanórai tevékenységek „gyakorlására” is lehetőséget biztosít.

Összefoglalásként elmondható, hogy a féléves gyakorlaton is az elsődleges feladat a szaktanári felkészités. Fontos információ ugyanakkor, hogy a tervezés, felkészülés és az utólagos értékelés kompetenciájának fejlesztése együtt legalább annyira fontos, mint magának a tanítási órának a megvalósítása. Ez egyfajta szemléletváltást, a folyamat egységben kezelését, a tudatosság szerepének megnövekedését is jelentheti.

Az elvárt és valós tevékenységek között nincs igazán nagy eltérés, s ami van, természetes módon magyarázható az iskolatípusok eltérő sajátosságaival. Furcsa tünetként kezelhető az iskolai adminisztráció jelentőségének kiemelése, a rangsor 4-5. helyére kerülése. A kérdőív összeállítása azzal a feltevéssel készült, hogy ez a „pedagógiai feladat” az utolsó lesz a rangsorban, s szakmailag nem is fogadható el, hogy megelözi a tanulókkal való egyéni bánásmód, a közösségépítés stb. kompetenciáját. Az adminisztrációs feladatok túlértékelése az intézményvezetők által indirekt módon tükrözi azt a felfokozott bürokráciát, amely ma a közoktatást sújtja.

A konkrét kérdésre, amely az optimálisnak ítélt és a megvalósított feladatelosztás közti eltérés indokaira vonatkozott, az igazgatók a következő magyarázatot adták. Általános korlátként fogalmazódott meg az

- igazodás a hallgató egyéni szükségleteihez (szakjához, előzetes szakmai tapasztalataihoz stb.); 
- igazodás az intézmény sajátos profiljához;

- igazodás az iskola aktuális féléves programjához;

- a mentor magas óraszámához.

A hallgatók válaszaiban az alábbiak indokok találhatók:

- túlterheltség, túlterhelt hallgató és túlterhelt mentor, sok feladat, aránytalanság;

- időhiány, a felkészülés időigénye;

- diákok, a gyerekek képességei, igényei és hozzáállása;

- iskola, az intézmény sajátosságai, igénye és müködése;

- hallgatói és mentori igényesség.

Az adatok alapján levonható az a következtetés is, hogy irreális és szakmai szempontból kifogásolható egységes, szigorú elöírásokat elrendelni, mivel a rendkívül eltérő élethelyzetek, intézményi sajátosságok stb. rugalmas megoldásokat tesznek szükségessé.

A pedagógiai kompetenciák fejlesztése

A féléves gyakorlat tartalmi kérdéseként a tevékenységek fontosságának vizsgálatán túl külön figyelmet fordítottunk egy feladat, a pedagógiai kompetenciák fejlesztésének vizsgálatára. Kérdéseink alapján azt kívántuk feltárni, hogy melyek azok a kompetenciaterületek, amelyek már a képzési szakaszban kialakulnak, s melyek azok, amelyek a féléves gyakorlat során indulnak komoly fejlödésnek. Az eredményességre vonatkozó kérdés alapján azt kívántuk megfogalmazni, hogy a kompetenciák folyamatos fejlesztése terén milyen szerepe van a képzésnek és a gyakorlati félévnek, s melyek azok a területek, amelyek a gyakornoki, illetve a folyamatos fejlődés későbbi időszakának feladati közé sorolhatók.

A 2. táblázat a nyolc pedagóguskompetencia fejlesztését támogató mentori segítség fontossági sorrendjét tartalmazza a hallgatók és a mentorok véleménye szerint. A mentori vélemények mellett megtalálható két rangszám a gyakorlat kezdetének és befejezésének időpontjára vonatkozik. A kettő közötti eltérések utalnak a féléves együttmüködés eredményességére, $\mathrm{s}$ a diploma megszerzése utáni gyakornoki időszak feladataira.

A válaszok összehasonlításánál és értékelésénél figyelembe kell venni, hogy a hallgatók visszaemlékezésük alapján csak egy értékelést adtak, nem differenciálva a gyakorlat kezdeti és befejező állapota szerint. 
2. táblázat: A kompetenciák fejlesztéséhez szükséges mentori támogatás mértéke a hallgatók és a mentorok rangsorolása alapján

\begin{tabular}{|l|c|c|c|}
\hline Pedagógiai kompetenciák & Hallgatók & \multicolumn{2}{|c|}{ Mentorok } \\
\hline Szaktárgyi, tantervi, szakmódszertani tudás & 4 & 5 & 5 \\
\hline Pedagógiai tervezés & 3 & 3 & 2 \\
\hline Tanulás támogatása & 6 & $7-8$ & $3-4$ \\
\hline Tanulói személyiség fejlesztése, egyéni bánásmód & 2 & 1 & 1 \\
\hline Tanulói közösség alakulásának és fejlődésének segítése & 1 & 4 & $3-4$ \\
\hline Pedagógiai értékelés & 5 & 2 & $6-7$ \\
\hline Kommunikáció és együttmüködés & 7 & 6 & 8 \\
\hline Szakmai fejlődésért való elkötelezettség & 8 & $7-8$ & $6-7$ \\
\hline
\end{tabular}

A két csoport megítélése között nagymértékü az egyetértés azoknak a kompetenciáknak a megnevezésében, amelyekre a képzés során eredményesen készítik fel a leendő tanárokat, ezek a kommunikáció és a szakmai fejlődés iránti elkötelezettség elkötelezettség, valamint a tanulás támogatása (8., 7., 3. kompetencia). Nem lehet ugyanakkor figyelmen kívül hagyni, hogy a harmadik kompetencia rangsora megváltozott a gyakorlat végére (3-4. hely). Ez következhet abból, hogy a többi terület nagymértékben fejlődött, de jelentheti azt is, hogy a valós tanítási helyzet újabb és újabb nehézségek elé állítja a hallgatókat, s ezen a területen folyamatosan fejlödő adaptivitásra és kreativitásra van szükség.

Két olyan terület van, ahol nagymértékü eltérést mutat a hallgatói és a mentori vélemény, a közösségek építésének segítése és a pedagógiai értékelés terén. Míg a közösségfejlesztés a hallgatók számára fontosabb, az értékelés kompetenciáját a mentorok érzik alacsony szintünek. Ugyanakkor ezen a téren tartják legeredményesebbnek a gyakorlat során végzett munkájukat (2. helyröl a 6-7. helyre változott a segítség szükségességének mértéke!).

Természetes módon a tanulói személyiség megismerése és az egyéni bánásmód megvalósítása terén van a legtöbb támogatásra szükség, s ez a pozíció marad a gyakorlat végére is. Sok tennivaló marad még a pedagógiai tervezés kompetenciájának fejlesztése terén is, hiszen ez a kompetencia integrálja mindazt a tudást és képességet, amely a szaktárgyi, szakmódszertani ismereteket és tanítási-tanulási tapasztalatok alkalmazó összefoglalását jelentik.

\section{Az összefüggő gyakorlat módszertani kérdései: a fejlödés támogatója, a mentor}

A kérdőív harmadik egysége a mentorálás fontosságára, a mentori szerepek/feladatok összegyüjtésére és súlyozására, a mentorok kiválasztásának módjaira stb. vonatkoztak. A mentorálás gyakorlata már hosszú múltra tekint vissza a hazai peda- 
gógusképzés rendszerében, bár a segítő tapasztalt kollégát más megnevezéssel illették/illetik a különböző képzési szinteken (szakvezető, vezetőtanár stb.). Ez a rendszer az esetek többségében a gyakorlóiskolákban müködött, müködik ma is, és magas szintủ pedagógiai munkájuk alapján kiválasztott kollégák végzik. A célzott mentorképzés csak néhány éves tapasztalatra támaszkodhat. A gyakorlati rendszer kiterjesztése olyan gyakorlóhelyekre, amelyek nem feltétlenül rendelkeznek kimagasló teljesítményekkel, sőt némelyikük éppen az ún. nehéz terepen müködik, szükségessé teszi egy létszámában megnövekedett, munkahely szerinti eloszlásában országos lefedettségű új pedagógusréteg felkészítését egyrészt a fél-, majd egy évessé váló képzési gyakorlat segítésére, másrészt a kezdő pedagógusok gyakornoki időszakának támogatására.

A kérdőív kérdése arra kérdezett, hogy az intézményvezetők szükségesnek tartják-e a mentori rendszer bevezetését, és válaszuk indoklását is kérte. A rendszer bevezetésével teljes mértékben egyetért minden válaszoló. A mentori segítő-támogató funkció hasznát több területen is megemlítették:

- „A mentor segíti át a hallgatót a katedra egyik oldaláról a másik oldalra”, azaz támogatja a pedagógusszerep és hivatás elfogadását, elmélyítését.

- A szakórák megtartásának támogatója, aki megfelelő visszajelzésekkel segíti a hallgatók fejlődését, alakítja önbizalmát.

- Nagyobb tapasztalattal rendelkező társ, akivel minden problémát meg lehet beszélni.

- Kritikus társ, aki az általa helytelennek, irreálisnak vélt elképzeléseket, prekoncepciókat szükség szerint korrigálja.

- Segítséget nyújt a további fejlődés irányának kijelölésében.

- Bevezeti a hallgatót a kollégák közösségébe, segít minél szélesebb körben megismerni az intézmény életét.

Az indokok egyharmad része az iskolai gyakorlat fontosságát emelte csak ki, s magáról a mentori feladatokról nem tett említést.

A spontán indoklások mellett egy irányítottabb kérdéssor ugyanebben a témakörben és a mentor személyére vonatkozóan kívánt információkat szerezni. A mentorságra vonatkozó állításokat három fokú skálán kellett értékelni. A rangsor kialakítása során az egyes fokozatokhoz pontokat rendeltünk, ahol a magasabb érték a fontosabbnak tartott feladatot jelentette (3. táblázat). 
3. táblázat: A mentori feladatok rangsora az intézményvezetők, hallgatók és mentorok véleménye szerint

\begin{tabular}{|l|c|c|c|}
\hline A mentori feladatokra vonatkozó állitások & Igazgatók & Hallgatók & Mentorok \\
\hline $\begin{array}{l}\text { A mentor feladata a gyakornok munkájának } \\
\text { folyamatos értékelése. }\end{array}$ & 1 & 4 & 1 \\
\hline $\begin{array}{l}\text { A mentor feladata a gyakornok óráinak } \\
\text { látogatása, értékelése. }\end{array}$ & $2-3$ & 2 & 3 \\
\hline $\begin{array}{l}\text { A mentor feladata az iskolai életbe való } \\
\text { bevezetés. }\end{array}$ & $2-3$ & 3 & 2 \\
\hline $\begin{array}{l}\text { A mentor feladata a gyakornok munkájának } \\
\text { közös megtervezése. }\end{array}$ & 4 & 6 & 7 \\
\hline $\begin{array}{l}\text { A mentor feladata a tanórán/iskolán kívüli } \\
\text { tevékenységekbe való bevezetés. }\end{array}$ & 5 & 5 & $5-6$ \\
\hline $\begin{array}{l}\text { A mentor feladata a gyakornok pedagógiai } \\
\text { kompetenciáinak fejlesztése egyéni feladatok } \\
\text { adásával. }\end{array}$ & 6 & 8 & 4 \\
\hline $\begin{array}{l}\text { A mentor támogató segítésének mértéke } \\
\text { a gyakorló szükségleteitöl függ. }\end{array}$ & 7 & 1 & $5-6$ \\
\hline $\begin{array}{l}\text { A gyakornok egyedül végezheti pedagógiai } \\
\text { tevékenységét, a mentor csak akkor szól bele } \\
\text { munkájába, ha a gyakornok kéri. }\end{array}$ & 8 & 7 & 9 \\
\hline $\begin{array}{l}\text { A mentor segít a hallgatói portfólió } \\
\text { elkészítésében, a reflektív gondolkodás } \\
\text { fejlesztésében. }\end{array}$ & 9 & 9 & 8 \\
\hline
\end{tabular}

A három rangsor összehasonlítása azt mutatja, hogy a vezetők és mentorok gondolkodása igen közel van, míg a hallgatóké két esetben markánsan, a többiben kisebb mértekben eltérő.

Az igazgatóknál és mentoroknál első helyet elfoglaló értékelö funkció a spontán válaszokból tükröződő „segítő társ“ attitűd után váratlan eredményként hat. Igaz, hogy az állítás nem jelöli, hogy az értékelés melyik formájáról van szó (diagnosztikus, formáló-segítő, összegző-minősítő), s lehet, hogy csak az elöítélet, rossz beidegződések okoznak negatív érzéseket. Az is látható, hogy a tanóralátogatásnak mindhárom csoport nagyon nagy szerepet tulajdonít, s közel azonos az elutasító véleményük a nagyfokú önállóság biztosításával (7-9. hely). Ugyanakkor a differenciált, az egyéni igényeket figyelembe vevő támogatást a pedagógusok inkább elutasítják (5-6. 7. hely), míg a hallgatók a legfonosabbnak tartják. Nagyon fontos, hogy ebben az esetben nem a mentori segítséget utasítják el, hiszen ezt a 7 . helyre sorolták, s ez inkább az állítás elvetését, mint elfogadását jelenti. Ez az eltérés ko- 
moly figyelmeztetés a differenciálás szükségességére vonatkozóan. Némileg ellentmond ennek a következtetésnek az egyéni feladatokon alapuló kompetenciafejlesztés 8 . ranghelye.

Fel kell figyelni a rangsor végére kerülő, a reflektivitás fejlesztésére és portfólió készítés segítésére vonatkozó állítás nagy mértékü elutasítására. Ez magyarázható azzal is, hogy a kérdőív kitöltésekor még idegen, a pedagógiai közvélemény által nem elfogadott szakmai elvárás fogalmazódott meg bennük.

A mentorok kiválasztásával kapcsolatos két kérdés (a mentor hallgatóval megegyező szakja és előzetes felkészítése; és a mentori munkát nehezítő tényezők) különböző válaszokat eredményezett. Míg teljes az egyetértés, hogy a mentor és hallgató azonos szakos legyen, az előzetes felkészítést sem a mentorok, sem pedig a hallgatók nem tartják igazán fontosnak.

Felmérésünkben arra az előzetes félelemre is választ szerettünk volna kapni, amely a rendszer bevezetését megelőző szakmai vitákban rendkívül nagy hangsúlyt kapott, mégpedig az a feltevés, hogy nem lesz elég pedagógus, aki a mentori munkát vállalja.

A válaszokból az a következtetés vonható le (elsősorban az igazgatói válaszok alapján), hogy ez jelenleg nem jelent gondot. Az országosan meginduló mentorképzések népszerüsége a pedagógusok körében szintén azt jelzi, hogy a mentori feladatkör igazi szakmai kihívásként fogalmazódik meg, ahol a pedagógusok saját szakterületükön belül végezhetnek újszerü, hasznos pedagógiai munkát, adhatják át mindazt a tapasztalatot és tudást, amelyet az évek, évtizedek alatt megszereztek. Segít ebben a folyamatban az életpályamodell bevezetése is.

Ugyanakkor a jövő érdekében nagyobb figyelmet kell szentelni a korlátozó, nehezítő tényezőkre, azok csökkentésén, megoldásán kell fáradozni, hogy a mentori rendszer stabilan beépüljön a pedagóguspálya folyamatába. Mik ezek a nehézségek a válaszok szerint?

- A szakmai elismerés biztosítása;

- a terhelés reális elosztása (óraszám kedvezmény);

- a gyakorlati idő tehermentesítése a gyakorló számára;

- szorosabb kapcsolat kiépítése a képzőintézmény és a gyakorlóhely között;

- nagyobb lehetőség a hallgatók értékelésében, pályaalkalmasságának megítélésében.

A felsorolás egybecseng azokkal a tanácsokkal, amelyeket az egyéves gyakorlat bevezetésének segítéséhez kértünk a kérdőív utolsó kérdéseként:

- A tanácsok/kérések egy része a mentorok munkakörülményeire vonatkoztak: kevesebb óraszám, minimális adminisztráció elvárása.

- A gyakorlóhely megválasztása megfelelő információk alapján és a szakos ellátottság figyelembevételével történjék. A gyakorlat szervezése időben kezdődjék, az intézmény kapjon előzetes tájékoztatást a kijelölt hallgató- 
ról, érdeklődéséről, egyes kompetenciáinak fejlettségéröl, hogy ezek alapján kapjon iskolai feladatokat.

- Felmerül egy olyan együttmüködés lehetősége, ahol a képzőintézmény nemcsak elfogadja az iskolák segítségét a gyakorlati képzésben, hanem kölcsönösségen alapuló együttmüködést is ajánl (továbbképzések terén, akciókutatásokban stb.).

\section{Az összefüggő egyéni gyakorlatra vonatkozó következtetések, javaslatok}

Egyértelmüen megfogalmazódik minden választ adó érdekelt fél részéről, hogy az összefüggő egyéni gyakorlat (a féléves és egyéves) rendkívül hasznos a leendő tanárok fejlődése szempontjából.

\section{A gyakorlat szervezési feladatai}

A szervezési feladatokra vonatkozó jelenlegi gyakorlat és annak kritikája elsősorban az intézményvezetők és a mentorok véleményei alapján összegezhetők.

A hallgatók elhelyezése az elmúlt években nem okozott különösebb gondot. Bár létrejött egy gyakorlóhelyeket tartalmazó „bank”, az elhelyezések csak ritkán történtek ennek alapján. A legtöbb gyakorló saját maga kereste meg az iskolát. Régi ismeretségek, előző tapasztalatok, információk segítették döntéseiket. Általában az intézmények befogadták a fiatal kollégákat, ritkán fordult elő elutasítás. A felmérésben részt vevők komoly hányada (egyötöde) mint gyakorló pedagógus, saját iskolájában „folytatta” munkáját. Az elkövetkező időszakban ezeknek a kollégáknak a száma csökkenni fog, hiszen a pedagógusképzési rendszer átalakításával a föiskolai végzettség egyetemi szintüre emelésére egyre kevesebb tanárnak lesz szüksége. Ha figyelembe vesszük a tanárképzés volumenének csökkenését és a mentorképzés kiszélesítését is, valószínüsíthető, hogy a gyakorlóhely kijelölése nem fog túl nagy gondot okozni.

Komolyabb szakmai kérdést vet fel a gyakorlat szervezésével kapcsolatos bizonytalanság, a kétféle intézmény munkaszervezése közti különbségek áthidalása. Míg a föiskolai-egyetemi rendszer a hallgatók egyéni igényeihez, élethelyzetéhez igazodva nagyon nagy szabadságfokkal szerveződik, a közoktatás müködése változatlanul szigorúan szervezett, s nagyrészt egységesen központilag irányított. Az ebből következő szervezési gondok megoldása a képzőintézmények feladata lehet, hiszen az iskolák változtatási lehetőségei igen korlátozottak. A nehézségek három területen sürüsödnek:

- A hallgatók a gyakorlat idejében is aktívan vesznek részt a képzésben a második, harmadik szakjukkal. Az intézményi órarend nem tudja figyelembe venni, hogy néhány hallgató a délelötti órákban iskolai elfoglaltsággal rendelkezik. 
- A tanév rendje eltér a két intézménytípusban. Optimális lenne, ha a hallgatók az iskolai tanév kezdetétől (augusztus végétől) részt vehetnének az előkészítés, tervezés munkálataiban, megismerkednének a tantestület tagjaival, munkájával. A januári hónapban viszont nagy valószínüséggel a mentorok szeretnék visszavenni osztályaikat, a megfelelő korrekciók, összefoglalások, értékelések megvalósítására.

- A gyakorlati követelmények megvalósításában kellő szabadságot kellene biztosítani a képzőintézmény részéröl, hogy a gyakorlóhely sajátosságaihoz lehessen illeszteni a hallgatói feladatokat. (Pl.: Az egyéni bánásmód kompetenciájának fejlesztése más típusú tevékenységében valósulhat meg az általános iskolában, szakiskolában vagy gimnáziumban.)

A szervezés és együttmüködés feladataihoz tartozik a képzőintézmény és a gyakorlóiskola közti szakmai kapcsolatok szorosabbá tétele. A jelenlegi problémák és a vágyak szintjén is megfogalmazódott, hogy a mentorok és intézményvezetők pontosabb felkészítést szeretnének kérni a gyakorlat céljáról, feladatairól, az értékelésről stb. Nagy valószínűséggel ez a hiányérzet csökkenni fog a mentorok képzésének kiterjesztésével (kötelezővé tételével). Ettől függetlenül reális igény az iskola vezetői részérôl is, hogy minden fontos információt megkapjanak még a gyakorlat kezdése előtt.

Megfogalmazódott egy „,valódi együttmüködés” gondolata is a két intézmény között. Olyan kölcsönös szakmai kapcsolatokat szeretnének kiépíteni, ahol az iskola nemcsak gyakorlóhely, hanem partner a képzésben, a különböző kutatásokban, innovatív megoldások kipróbálásában, bevezetésében, s a képzőintézmény segítő az iskola szakmai problémáinak megoldásában. Ez a spontán módon megfogalmazott elképzelés megfelel a szakirodalomból már ismert „szakmai fejlesztő/fejlődő iskolák” kialakuló hálózatának (Kotschy, 2003).

\section{A gyakorlat tartalmi kérdései}

A gyakorlat tartalmi kérdéseit kétféle megközelítésben igyekeztünk feltárni, egyrészt a tevékenységek, másrészt a pedagógiai kompetenciák oldaláról.

A gyakorlat során végzett feladatok, pedagógiai tevékenységek a központi javasoltaknak megfelelően kerültek a kérdőívbe, így kiegészítésükre vagy megváltoztatásukra nem volt mód. A felmérés egyértelmüen igazolta, hogy a tevékenységi területekkel kapcsolatos elvárások irreális követelményeknek bizonyultak. Ezért célunk nem a tevékenységi lista gazdagítása, hanem a tevékenységek fontosságának belső súlyozása volt.

A gyakorlat legfőbb tevékenysége a vártnak megfelelően a szaktanári feladatok, ezen belül a szakórák megtartása volt. Az órákra való felkészüléssel és az óra utáni elemző-értékelő beszélgetéssel együtt az összes idő kb. 60 százalékát tette ki. 
Ez az eredmény világosan mutatja, hogy a csoportos tanítási gyakorlat során megszerzett tapasztalatok nem alapozzák meg megfelelő szinten a tanítási képességek fejlődését, szükség van a folyamatos segítséggel és értékeléssel kísért további gyakorlásra. Ugyanakkor magyarázható azzal is, hogy általában a szaktanári, s kiemelten a középiskolai munka tanóra-centrikus, s a magas kötelező óraszámok a munkaidő döntő hányadát foglalják le.

A válaszolók eltérő véleménye egyes tevékenységek arányára vonatkozóan mindhárom csoport esetében alapvetően az intézmény típusától, belső feladatrendszerétől függ. Egyértelmü azonban, hogy azok a tanórán kívüli tevékenységek, amelyek szorosan összefüggnek a szaktárgy tanításával (tehetséggondozás, korrepetálás, tanulószobai foglalkozás stb.), alig férnek bele a gyakorlat idejébe. Ennek a problémának a megoldása alapvetően a gyakorlati idő meghosszabbításában rejlik, de azért érdemes felhívni a mentorok, igazgatók figyelmét ezekre a tevékenységekre, s tudatosan törekedni arra, hogy a hallgatók ezen a téren is szerezhessenek tapasztalatokat. Az iskolai élet megismerése, az egyes programokban való tevékeny részvétel nemcsak hasznos, hanem a hallgatók igényeit is szolgálná.

Kétségeket támaszt azonban az intézményvezetők szerint kiemelten kezelt adminisztratív feladatokban való jártasság megszerzése. Az oktatáspolitikai elvárások új irányvonala nem a pedagógiai munka fejlődését, hanem elsősorban az ellenőrizhetőség célját szolgálja, azért nem kellene a fiatal kezdő pedagógusokkal szemben is a lényeges, korszerü pedagógiai elvárások helyett a bürokratikus elemeket erősíteni. A szakmai gyakorlat során az önálló, alkotó, a gyermekek fejlődését szem előtt tartó pedagógiai tevékenységre való felkészítésnek kell lennie a meghatározónak.

A pedagógiai kompetenciák és fejlesztésük terén a 2013. EMMI rendeletben meghatározott képzési és kimeneteli követelmények alapján fogalmaztuk meg kérdéseinket. Az adatok elsősorban arra vonatkoznak, hogy melyek azok a kompetenciák, amelyeknek a fejlesztésére a képzés során nincs elég lehetőség, s ezért a gyakorlat folyamán a legtöbb segítséget igénylik. Mivel a mentoroktól a gyakorlat kezdetén és végén lévő állapotot is kérdeztük, három rangsor alapján a következő kép rajzolódott ki:

- Természetes hiány, hogy a képzőintézményben eltöltött évek alatt a hallgatóknak kevés lehetőségük van valós pedagógiai szituációban tevékenykedni, ezért a tanulói személyiségfejlesztés és a közösségalakitás támogatásának kompetenciája terén nincs tapasztalatuk. Ebben egyetértenek hallgatók és mentorok egyaránt.

- Kevésbé magyarázható a tervezési kompetencia fejletlensége, hiszen a különböző pedagógiai tervek készítésének feladatai hasznosak lehetnek az elméleti tanulmányok gyakorlati alkalmazásánál. (Pl. fiktív csoportok részére készített tematikus- és óra tervek, erdei iskolai, tanulmányi kirándulási tervek készítése). Hasonlóképp a csoportos tanítási gyakorlat során is fontos feladat 
a tanítási egységre való felkészülés. A bizonytalanságokat tükröző segítségkérés fontos visszajelzés ezáltal a képzőintézmény oktatói számára is.

- Két kompetencia a „középmezőnyben” foglal helyet. A pedagógiai értékeléssel való elégedettség valószínüleg abból fakad, hogy a hallgatók ezen a téren nem kerülnek igazán éles helyzetbe, s így nincs rajtuk a teljes felelösség. Ugyanakkor a diagnosztizáló, segítö-támogató értékelésre, illetve feladatsorok, témazárók önálló készítésére nagyon jó lehetőséget nyújthat a gyakorlat, amit a mentori értékelés szerint valóban ki is használnak, hiszen a segítség szükségességére vonatkozó rangsorban a kezdeti 2 . helyröl a 6-7. helyre kerül ez a kompetencia. A másik középen elhelyezkedő „tanulás támogatása" kompetencia igen eltérő értékelést kapott. Mentoroknál a kezdeti 7. helyröl a gyakorlat végén a 3-4. helyre került, s a hallgatók is a 4. hellyel értettek egyet. Úgy tünik, az a mentori elvárás, hogy a hallgatók a tanításról már megfelelő tapasztalati tudással rendelkeznek, nem egészen bizonyult igaznak. Ezt jelzi pl. az a mentor, aki a hallgatók módszertani tudását kifogásolja.

- A kommunikációs, együttmüködési kompetencia olyan alapvető képességekre épül, amelyekkel a hallgatóknak rendelkezniük kell már a képzés alatt is. Felmerül azonban a kérdés, hogy pl. a szülökkel, kollégákkal, más szakemberekkel való érintkezésre, együttmüködésre van-e lehetőségük a gyakorlóknak, valóban kevés segítségre szorulnak-e ezen a téren is.

- A szakmai fejlödésért való elkötelezettség utolsó helye a rangsorban érthető, de nem teljesen megnyugtató. A belső igényesség, motiváltság kialakításának feladata szorosan összefügg a következőkben tárgyalt mentori feladatok értelmezésével.

Ha a két tartalmi megközelítés eredményeit összehasonlítjuk, levonhatjuk azt a következtetést, hogy a hallgatók megerösítést kapnak a tanításhoz közvetlenül kapcsolódó kompetenciák terén, de éppen a leghiányosabb pedagógiai kompetenciák, a tanulói személyiség megismerése, az egyéni, differenciált bánásmód és a közösségfejlesztés segítéséhez szükséges képességek fejlesztésére igen kevés idő és feladat jut. Az egyéves gyakorlat kidolgozásánál ezt feltétlenül figyelembe kell venni.

\section{A mentori feladatok ellátásához szükséges tevékenységek}

A mentorok és mentorálás fontossága egyaránt elfogadott mind a három megkérdezett csoport részéröl. Külön figyelmet érdemel az az egyezés is, amely az intézményvezetők és a mentorok válaszai között található a mentorság lényegi feladatainak megfogalmazásáról:

- a mentor-hallgató viszonyt elsősorban a szülö-gyerek kapcsolathoz hasonlítják a metaforákban; 
- a legfontosabb feladatként a folyamatos követést-értékelést fogalmazzák meg;

- $\quad$ s a legkevésbé értenek egyet a hallgatói önállóság mértékének növelésével.

Úgy tünik, a szerepfelfogás sokkal közelebb áll a diák-tanár viszonyhoz, mint a fiatal és a tapasztalt kolléga közti együttmüködéshez. A hallgatói és a mentori válaszok közti szignifikáns eltérések viszont azt mutatják, hogy a hallgatók nagyobb önállóságra vágynak, kevésbé érzik a folyamatos értékelés fontosságát. Ez a kérdés egy általánosabb oktatáspolitikai problémára hívja fel a figyelmet. Az előírásoknak való megfelelés fontossága, az önállóságtól való félelem, a vezetettség, a beosztotti, végrehajtó szerep természetes elfogadása még 25-30 év után is meghatározza a hazai pedagógustársadalomról kialakított társadalmi képet, a pedagógusok életérzését. Természetesen, egy kérdőíves felmérés szük körü eredményeiből nem lehet meszszemenő következtetéseket levonni, de az a pedagógiai légkör, amely jelenleg körülveszi a változtatási szándékokat, $\mathrm{s}$ néha az az oktatáspolitikai elképzelés a pedagógusokról, amely az oktatáspolitikai törekvésekben - akár a legnagyobb jóindulattal is megnyilvánul, nem a jövő céljait és pedagógusképét veszi figyelembe, nem az önálló gondolkodású, innovatív pedagógusokat segíti, hanem a gyengékhez igazítva alakítja a rendszer irányítását, müködési szabályait.

Ezért fontos feladat, hogy a kezdő pedagógusok ösztönzést kapjanak egyéni elképzeléseik kidolgozásához, kipróbálásához, s az eredmények elemzéséhez, értékeléséhez. Ez a megközelítés éppen a rugalmasság, a reflektivitás és az önálló hallgatói kezdeményezések támogatását hangsúlyozza a mentori munkában, $\mathrm{s}$ amelyeket a mentorok és vezetők jelenleg egyaránt a legkevésbé fontosként említettek.

A pedagógiai nézetek átalakítása a képzések, továbbképzések, oktatáspolitika közös feladata. A korszerü tanulással-tanulókkal kapcsolatos nézetek egyre szélesebb körben elfogadottak, s talán ez segíthet a tanárokról alkotott elképzelés, elvárás-rendszer megújításában is.

Fontos fejlődés, hogy a pedagógussá válást folyamatként értelmezzük, ami a képzés befejeztével nem válik teljessé, de az önálló, alkotó pedagógussá válást a pedagógiai szabadság folyamatos növelésével lehet csak elérni. Ebben a folyamatban kell megtalálni az egyéni szükségletekhez alkalmazkodó egyéves tanítási gyakorlat feladatait, követelményeit.

\section{Irodalom}

A 289/2005 (XII.22) Kormányrendelet 13.§ kiegészítése: Ajánlás a tanári mesterszak öszszefüggő szakmai gyakorlati félévének tartalmáról (2009. XII. 30.).

A 326/2013 (VIII.30.) Kormányrendelet a pedagóguskompetenciákról.

Kotschy Beáta (2003): Szakmai fejlesztö/fejlődő iskolák - A pedagógusképzés megújításának egy lehetösége. Pedagógusképzés, 1-2. sz. 109-117. 